\title{
Finite Element Analysis of Carbon Fibre Reinforced Aircraft Wing
}

\author{
Kirankumar Reddy ${ }^{1}$, Sunil Manganshetty ${ }^{2}$ \\ ${ }^{I}$ M.Tech Scholar, Mechanical Engineering Dept., PDA College of Engineering, Gulbarga, India \\ ${ }^{2}$ Professor, Mechanical Engineering Dept., PDA College of Engineering, Gulbarga, India
}

\begin{abstract}
Subsonic aircraft is used as business jets and commercial airplanes. The wings are usually straight or with low sweep angle. The main group of materials used in aircraft construction has been wood, steel, aluminum alloys and more recently, titanium alloys and fiber reinforced composites. Several factors influence the selection of material of which strength allied to lightness is the most important. Composite materials are well known for their excellent combination of high structural stiffness and low weight.CFC is seen to have a modulus twice \&strength three times that of aluminum alloy, the conventional material used in aircraft construction. In the present work the aircraft wing components skin is analyzed considering both isotropic and composite materials. The parametric study conducted using MSc Nastran finite element package. From the studies conducted regarding the weight reduction, it is estimated that replacement of Al. alloy by CFC results in $52.96 \%$ saving in the total structural weight of the aircraft wing.
\end{abstract}

Keywords: CFC, Finite Element Model, ply orientation, Skin, Static Analysis, Subsonic wing.

\section{Introduction}

For aerodynamic reasons, the wing cross-section must have a streamlined shape commonly referred to as an airfoil section. The aerodynamic forces in flight change in magnitude, direction and location. Likewise in the various landing operations the loads change in magnitude, direction and location, thus the required structure must be one that can efficiently resist loads causing combined tension, com-press ion, bending and torsion. To provide tensional resistance, a portion of the airfoil surface ribs be covered with a metal skin and then adding one or more internal metal webs to produce a single closed cell or a multiple call wing cross-section. The external skin surface which is relatively thin for subsonic aircraft is efficient for resisting tensional shear stresses and tension, but quite inefficient in resisting compressive stresses due to bending of wing. To provide strength efficiency, span-wise stiffening units commonly referred to as flange stringers are attached to the inside of the surface skin. To hold the skin surface to airfoil shape and to provide a medium for transferring surface air pressures to the cellular beam structure, chord wise formers and rids are added. To transfer large concentrated loads into the cellular beam structure, heavy ribs, commonly referred to as bulkheads, are used. In this work the wing structure is optimized by conducting several iterations for the spars, ribs, wing skin. In each iteration the sizing of the structure is done at the final iteration the optimized structure is obtained still there is a scope for reducing weight for replacing the metallic wing skin by composite. The composite wing skin is analyzed for the required straight consideration. There is a considerable reduction in the weight of $52.96 \%$ in the wing by top and bottom skin

Most of the aircraft produced are subsonic aircrafts Which are designed to fly below Mach 0.8 small light weight airplanes have lower Mach number which is around mach0.2.Business jets and commercial airlines can fly at maximum speeds up to mach0.85.Light subsonic aircrafts use piston engines as the power plant while business jets and commercial airlines use turboprop or by pass turbofan. Structurally the loading on the air frame varies from plane to plane. The wings are usually straight or with low sweep angle. Typically speeds for subsonic aircrafts are less than610 mph and Mach number M 1<0.8.It flies below the speed of sound.

\section{Materials And Method}

2.1 Configuration of Subsonic Aircraft Wing

The wing of subsonic aircraft considered in the present study is rectangular taper wing. The cross section of the wing is aero foil. The wing has a root chord of $1500 \mathrm{~mm}$ and tip chord of $650 \mathrm{~mm}$. The various structural components of a subsonic aircraft wing structure considered are:

- Panels-Top and Bottom skin.

- Spars-Front and Rear spar.

- Ribs-Root rib, Ribs1, 2, 3,4,5,6 and Tip Rib

The air loads act directly on the wing cover, which transmits the loads to the ribs. The ribs transmit the loads to the spar webs and distribute the load between them in proportion to the web stiffness. The use of several spars permit a reduction in rib stresses and also provides a better support for the span wise bending 
Ribs are used to hold the panel to contour shape. The rib also has another major purpose, to transfer or distribute the loads. The ribs provide stability to spars and panels. The primary function of the wing skin is to form an impermeable surface for supporting the aerodynamic pressure distribution from which the lifting capability of the wing is derived

\subsection{Structural Layout}

The front spar of aircraft wing is placed about $15 \%$ of the wing chord and longitudinal axis to facilitate mounting of leading edge and provide space for accommodating landing gear . The rear spar of aircraft wing is placed about $68 \%$ of wing chord to facilitate mounting of control surfaces. The rear spar is oriented normal to the fuselage axis for better load transfer.Seven ribs are connected to the spars to form the structural frame. The skin of the wing is made in two parts and placed over the spars and ribs at top and bottom

The primary objective is to optimize the wing thickness so several iterations are carried to reduce weight of wing including spar, rib, and skin. At the third iteration the optimize structure is obtained. Then the skin is replaced by metallic to composite. (CFC), a composite laminate material for the wing panel effectively reduces the weight of the wing. Weight reduction and lower productions costs are important goals for aircraft structural engineers and researchers. The use of advanced composite structures has increased to realize these goals

\subsection{Wing Model}

The model consists of a subsonic aircraft wing . The various structural components are top and bottom panels, seven ribs and front and rear spars. To study the effects of composite laminate when compared to conventional material on wing structures, the panels were modeled as orthotropic CFC laminates and remaining components were modeled as isotropic material.

The orthotropic materials properties are given in table.1 and the material properties of isotropic are given in table 2

\subsection{Analysis Method}

MSC-Nastran is a general purpose fem package for numerically solving a wide variety of problems. In this experimental analysis the wing model was first generated in catiaV-5 and then the model is imported to hyper mesh for generating mesh and then the mesh model is further allowed to run in the Nastran software and by adding material properties in pastran software and further analysis results are obtained.

\section{Results And Discussion}

The static analysis of the air craft wing has been done using the pre and post processing of finite element model using Hyper mesh and solving in MSC/Nastran. The total weight of the aircraft wing made of the conventional material was seen to be $25.85 \mathrm{~kg}$ while that replaced with CFC weighed only $13.55 \mathrm{~kg}$. Hence the replacement of aluminum alloy by CFC reduces the total aircraft of the wing by $52.96 \%$ there by reducing the total weight of the aircraft tremendously

IV. Figures And Tables

Table 1: Material Properties of Al. Alloy

\begin{tabular}{|c|c|}
\hline MATERIAL PROPERTY & ALLUMINIUM \\
\hline MOD.OF ELASTICITY & $7000 \mathrm{mpa}$ \\
\hline MASS DENSITY & $2823 \mathrm{~kg} / \mathrm{m} 3$ \\
\hline POISSON'S RATIO & 0.35 \\
\hline TENSILE STRENGTH & 460 \\
\hline
\end{tabular}

Table 2: following isotropic composite properties with symmetric balanced layups are shown

\begin{tabular}{|c|c|}
\hline No. of layers & 12 \\
\hline Thickness $=(.12 * 12)$ & $1.44 \mathrm{~mm}$ \\
\hline Elastic modulus 11 & 13000 \\
\hline Elastic modulus 22 & 10000 \\
\hline Poisons ratio12 & 0.349 \\
\hline Shear modulus & 5000 \\
\hline Tension stress limit 11 & $132 \mathrm{~N} / \mathrm{mm} 2$ \\
\hline Tension stress limit 22 & $60 \mathrm{~N} / \mathrm{mm} 2$ \\
\hline Shear stress limit & $36 \mathrm{~N} / \mathrm{mm} 2$ \\
\hline Bending shear stress limit & $80 \mathrm{~N} / \mathrm{mm} 2$ \\
\hline
\end{tabular}

Table 3: Lodes acting on wing station 
Finite Element Analysis of Carbon Fibre Reinforced Aircraft Wing

\begin{tabular}{|l|l|}
\hline Wing station no & Aerodynamic loads in newton \\
\hline 1 & 25491.9 \\
\hline 2 & 23805 \\
\hline 3 & 20700 \\
\hline 4 & 17250 \\
\hline 5 & 13800 \\
\hline 6 & 8050 \\
\hline 7 & 5976 \\
\hline
\end{tabular}

Table 4: Comparison of share force bending moment and twisting moment for the following given lodes

\begin{tabular}{|l|l|l|l|l|}
\hline $\begin{array}{l}\text { Station } \\
\text { number }\end{array}$ & Load(N) & Shear force(N) & $\begin{array}{l}\text { Bending moment(N- } \\
\mathrm{mm})\end{array}$ & $\begin{array}{l}\text { Twisting } \\
\text { moment(N-mm) }\end{array}$ \\
\hline 7 & 5976 & 5976 & 0 & 2378448 \\
\hline 6 & 8050 & 14026 & 3286800 & 4025000 \\
\hline 5 & 13800 & 27826 & 10299800 & 7003500 \\
\hline 4 & 17250 & 45076 & 24212800 & $1 \mathrm{E}+07$ \\
\hline 3 & 20700 & 65776 & 46750800 & $1.4 \mathrm{E}+07$ \\
\hline 2 & 23805 & 89581 & 79638800 & $2.1 \mathrm{E}+07$ \\
\hline 1 & 25491.9 & 115072.9 & 124429300 & $2.4 \mathrm{E}+07$ \\
\hline
\end{tabular}

Table 5: Maximum value of FE stress for aluminum material

\begin{tabular}{|c|c|}
\hline Wing component & FE Stress in (N/mm2) \\
\hline Front spar & 373 \\
\hline Rear spar & 452 \\
\hline Top skin & 412 \\
\hline Bottom skin & 202 \\
\hline Ribs & 202 \\
\hline Root rib & 373 \\
\hline
\end{tabular}

Table 6: Reserve Factors at Ultimate Loads for composite wing skin

\begin{tabular}{|c|c|c|c|c|c|c|c|}
\hline SL.No. & COMPONENT & $\begin{array}{l}\text { MATERIAL. } \\
\text { SPECIFICATION }\end{array}$ & $\begin{array}{c}\text { TYPE OF } \\
\text { Stress/STRAIN }\end{array}$ & $\begin{array}{c}\text { DEVELOPED } \\
\text { STRAIN } \\
\text { ( } \square \text { s)/Stress(Mpa) }\end{array}$ & $\begin{array}{l}\text { ALLOW } \\
\text { STRAIN } \\
\quad(\square \mathbf{s})\end{array}$ & $\begin{array}{c}\text { RESERVE } \\
\text { FACTOR }\end{array}$ & REMARKS \\
\hline \multirow{6}{*}{1} & \multirow{6}{*}{ TOP SKIN } & \multirow{6}{*}{$\mathrm{CFC}$} & $\begin{array}{c}\text { Max Principal } \\
\text { Stress }\end{array}$ & 428 & 432 & 1.01 & $\begin{array}{c}\mathrm{RF}>1 \\
\text { structure is } \\
\text { safe }\end{array}$ \\
\hline & & & $\begin{array}{l}\text { Minimum } \\
\text { principal Stress }\end{array}$ & 320 & 560 & 1.75 & $\begin{array}{l}\mathrm{RF}>1 \\
\text { structure is } \\
\text { safe }\end{array}$ \\
\hline & & & $\begin{array}{l}\text { Max shear } \\
\text { stress }\end{array}$ & 41 & 80 & 1.95 & $\begin{array}{l}\mathrm{RF}>1 \\
\text { structure is } \\
\text { safe }\end{array}$ \\
\hline & & & $\begin{array}{l}\text { Major Principal } \\
\text { Strain }\end{array}$ & 3280 & 3400 & 1.03 & $\begin{array}{l}\mathrm{RF}>1 \\
\text { structure is } \\
\text { safe }\end{array}$ \\
\hline & & & $\begin{array}{l}\text { Minor principal } \\
\text { strain }\end{array}$ & 2720 & 3900 & 1.43 & $\begin{array}{l}\mathrm{RF}>1 \\
\text { structure is } \\
\text { safe }\end{array}$ \\
\hline & & & Failure index & 0.88 & 1.0 & 0.88 & $\begin{array}{c}\text { Failure } \\
\text { Index }<1 \\
\text { structure is } \\
\text { safe }\end{array}$ \\
\hline \multirow{4}{*}{2} & \multirow{4}{*}{$\begin{array}{l}\text { BOTTOM } \\
\text { SKIN }\end{array}$} & \multirow{4}{*}{$\mathrm{CFC}$} & $\begin{array}{l}\text { Max Principal } \\
\text { Stress }\end{array}$ & 390 & 432 & 1.1 & $\begin{array}{l}\mathrm{RF}>1 \\
\text { structure is } \\
\text { safe }\end{array}$ \\
\hline & & & $\begin{array}{c}\text { Minimum } \\
\text { principal Stress }\end{array}$ & 510 & 560 & 1.09 & $\begin{array}{l}\mathrm{RF}>1 \\
\text { structure is } \\
\text { safe }\end{array}$ \\
\hline & & & $\begin{array}{l}\text { Max shear } \\
\text { stress }\end{array}$ & 36 & 80 & 2.2 & $\begin{array}{l}\mathrm{RF}>1 \\
\text { structure is } \\
\text { safe }\end{array}$ \\
\hline & & & Major Principal & 2100 & 3400 & 1.61 & $\mathrm{RF}>1$ \\
\hline
\end{tabular}


Finite Element Analysis of Carbon Fibre Reinforced Aircraft Wing

\begin{tabular}{|c|c|c|c|c|c|c|c|}
\hline & \multirow{3}{*}{\begin{tabular}{|l|}
$\mid$ \\
$\mid$
\end{tabular}} & \multirow{3}{*}{\begin{tabular}{|l}
$\mid$ \\
\end{tabular}} & Strain & & & & $\begin{array}{l}\text { structure is } \\
\text { safe }\end{array}$ \\
\hline & & & $\begin{array}{l}\text { Minor principal } \\
\text { strain }\end{array}$ & 3200 & 3900 & 1.21 & $\begin{array}{l}\mathrm{RF}>1 \\
\text { structure is } \\
\text { safe }\end{array}$ \\
\hline & & & Failure index & 0.92 & 1.0 & 0.92 & $\begin{array}{c}\text { Failure } \\
\text { Index }<1 \\
\text { structure is } \\
\text { safe }\end{array}$ \\
\hline
\end{tabular}

Table 7: Comparison of weight reduction between CFC and aluminium alloy

\begin{tabular}{|l|l|l|l|l|}
\hline $\begin{array}{l}\text { METALLIC } \\
\text { SKIN }\end{array}$ & & & & \\
\hline COMPONENT & Volume $(\mathrm{mm} 3)$ & Density(Kg/mm3) & Mass kg & \\
\hline Bottom skin & 4723104.00 & $2.70 \mathrm{E}-06$ & 12.75 & \\
\hline Top skin & 4753136 & $2.70 \mathrm{E}-06$ & 12.83 & \\
\hline $\begin{array}{l}\text { COMPOSITE } \\
\text { SKIN }\end{array}$ & & & & \\
\hline COMPONENT & Volume(mm3) & Density(kg/mm3) & Mass kg & \\
\hline Bottom skin & 4723104.00 & $1.27 \mathrm{E}-06$ & 6.00 & \\
\hline Top skin & 4753136 & $1.27 \mathrm{E}-06$ & 6.04 & \\
\hline $\begin{array}{l}\text { OOTAL WEIGHT } \\
\text { SAVING }\end{array}$ & Mass(kg)-metallic & $\begin{array}{l}\text { Mass(kg)- } \\
\text { composite }\end{array}$ & $\begin{array}{l}\text { Weight } \\
\text { saving(kg) }\end{array}$ & \%wt. saving \\
\hline Bottom skin & 12.75 & 5.99834208 & 6.75 & 52.96 \\
\hline Top skin & 12.83 & 6.03648272 & 6.80 & 52.96 \\
\hline
\end{tabular}

CAD Model with dimension

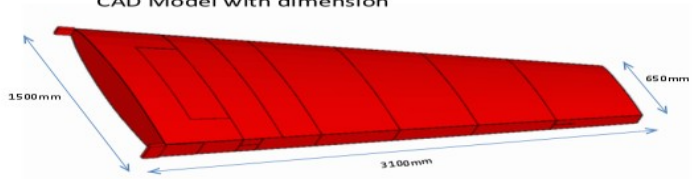

Figure 1: Wing Model

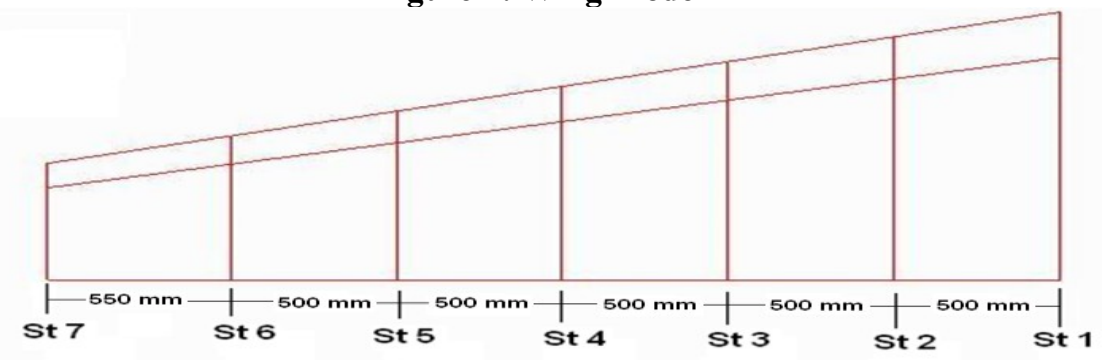

Figure 2: Station diagram of the wing

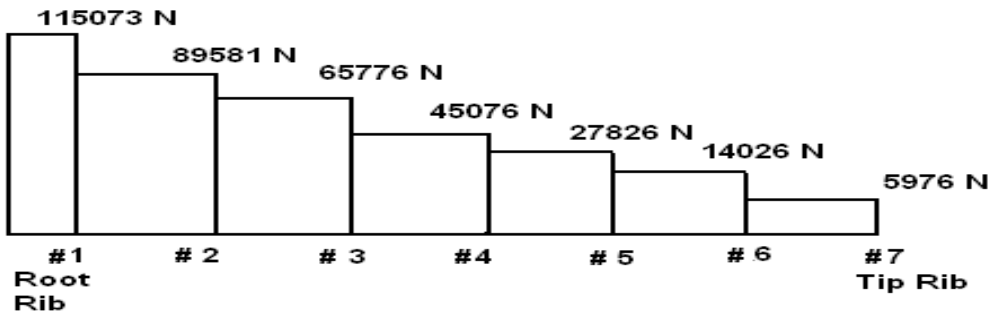

Figure 3: Wing shear force diagram 


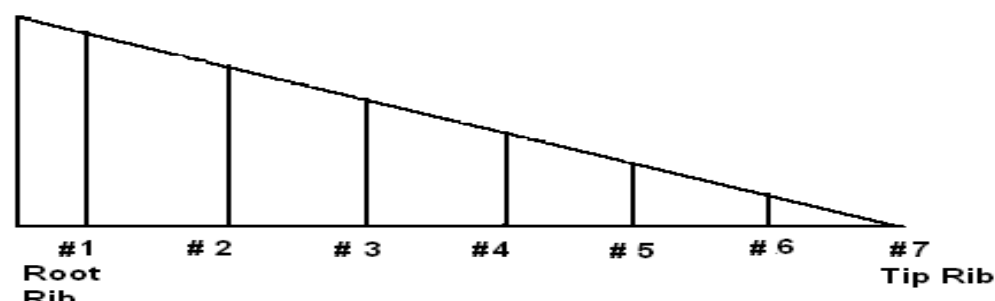

Figure 4: Wing bending moment diagram

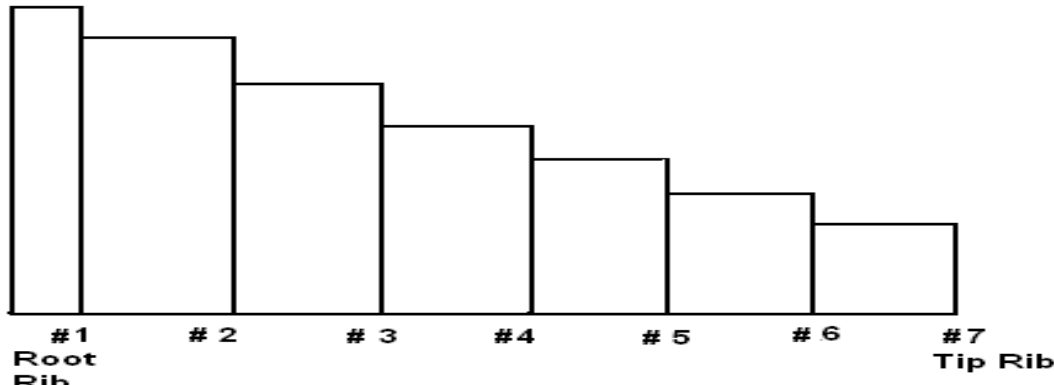

Figure 5: Wing twisting moment diagram

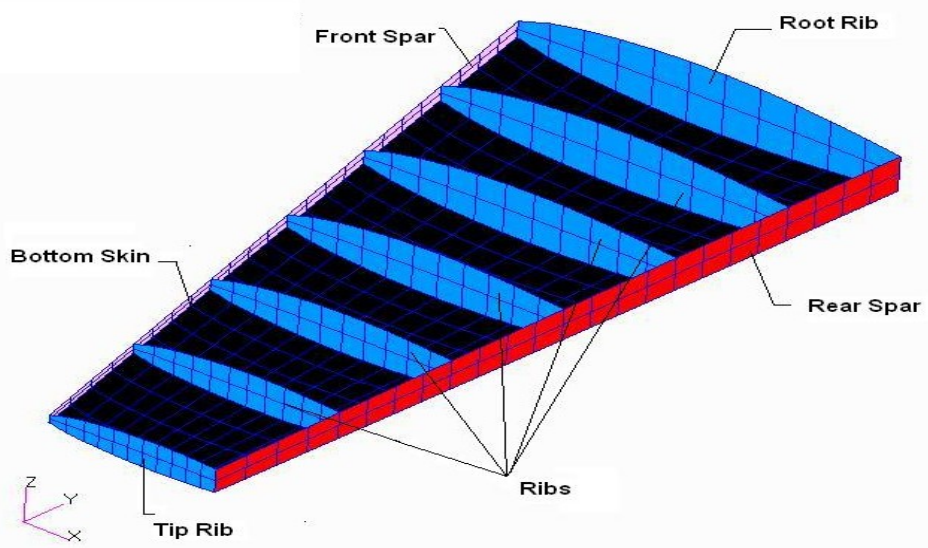

Figure 6: wing model in hyper mesh

The combined wing was then analyzed using the MSc Nastran software to obtain the max. value of stress.

\section{Conclusion}

Since preliminary design of the wing structures carried out as per the industrial practices for the given applied loads by iteration process and we carried out 3 iterations for metallic structure and at iteration 3 we got the optimum structure and in iteration 4 the metallic wing skin, bottom and top is replaced with CFC and we have seen there is a weight saving of $52 \%$ as still there is a scope for weight reduction of this wing structure by replacing the metallic ribs and spars by composites. This is consider for the future scope of the project

\section{References}

[1] Numerical Analysis Of Carbon Fiber Reinforced Aircraft wing by "SanyaMariaGomez"

[2] Air frame structural design by "MICHAELCHUN-YUNG NIU"

[3] Topology Optimization of Aircraft Fuselage Structure by “ MuniyasamyK alanchiam and BaskarMannai”

[4] Finite Element Analysis of aircraft wing using composite structure by "Dr.R.Rajappan,V.Pugazhenthi"

[5] Finite Element ModellingAnd Analysis Of Skin Panel Based On The Fiber Orientation And Stacking Sequence by "Dr.R.Rajappan,Dr.S.Sundararaj and V.Pugazhenthi”"

[6] Hybrid Wing-Body Pressurized Fuselage and Bulkhead,Design and Optimization by "VivekMukhopadhyay" 